\title{
PENGARUH ASUPAN TINGGI SERAT DAN CAIRAN TERHADAP TERJADINYA KONSTIPASI PADA LANSIA
}

\author{
Agus Sutarna*Asiah**Nila Purmula Sari***
}

\begin{abstract}
ABSTRAK
Salah satu cara yang dapat digunakan untuk mencegah terjadinya konstipasi adalah terapi asupan tinggi serat dan cairan yang cukup. Konstipasi adalah persepsi gangguan buang air besar berupa berkurangnya frekuensi buang air besar, sensasi tidak puas/lampiasnya buang air besar, terdapat rasa sakit, perlu ekstra mengejan atau feses yang keras. Tujuan penelitian ini adalah untuk mengetahui pengaruh asupan tinggi serat dan cairan yang cukup terhadap terjadinya konstipasi pada lansia di Panti Wredha Wilayah Cirebon Tahun 2017. Jenis penelitian ini menggunakan penelitian pre experiment. Populasi dalam penelitian ini adalah semua lansia di panti wredha wilayah cirebon sejumlah 28 orang. Teknik pengambilan sampel dalam penelitian ini menggunakan total sampling. Sampel yang digunakan dalam penelitian ini adalah sampel yang ditemui saat dilakukan penelitian. Hasil penelitian menunjukan bahwa sebelum diberikan asupan tinggi serat dan cairan sebagian besar mengalami konstipasi sebanyak 24 orang $(85,7 \%)$. sesudah diberikan asupan tinggi serat dan cairan semua responden mengalami asupan tinggi serat dan cairan cukup sebanyak 28 orang (100\%). Pengujian dengan menggunakan uji wilcoxon menunjukan bahwa nilai $\mathrm{p}<0,05$ yaitu 0,046 maka Ho ditolak dan Ha diterima berarti terapi asupan tingi serat dan cairan berpengaruh terhadap penurunan terjadinya konstipasi.
\end{abstract}

Kata Kunci : Asupan tinggi serat, konstipasi

\begin{abstract}
One way that can be used to prevent the occurrence of constipation is using a high intake of fiber and adequate fluids theraphy. Constipation is a perception of defecation in the form of reduced frequency of defecation, sensation of dissatisfaction/alloy defecate, there is pain, need extra strain or hard stool. The purpose of this study was to determine the influence of high intake of fiber and fluid sufficient to the occurrence of constipation in the elderly in Panti Wreda Cirebon Area Year 2017. This type of research uses pre experiment research. The population in this study is all 28 elderly in nursing home cirebon region. Sampling technique in this study using total sampling. The sample used in this research is the samples encountered during the research. The results showed that before given the high intake of fiber and liquid most constipation experience as many as 24 people (85.7\%). After being given a high intake of fiber and fluids all respondents experienced a high intake of fiber and fluids quite as much as 28 people (100\%). Tests using wilcoxon test showed that the p value <0.05 is 0.046 then Ho is rejected and Ha accepted means high intake therapy of fiber and fluid effect on the decrease of constipation.
\end{abstract}

Keywords : High intake of fiber, constipation

\footnotetext{
* Staf Pengajar Program Studi S1 Keperawatan STIKes Cirebon

** Staf Pengajar Program Studi S1 Keperawatan STIKes Cirebon

***Alumni PSIK STIKes Cirebon Lulus Tahun 2017
} 


\section{PENDAHULUAN}

Saat ini, di seluruh dunia jumlah orang lanjut usia diperkirakan ada 500 jutadengan usia rata-rata 60 tahun dan diperkirakan pada tahun 2025 akan mencapai 1,2 milyar lansia. Di Negara maju seperti Amerika Serikat pertambahan orang lanjut usia \pm 1.000 orang per hari pada tahun 1985 dan diperkirakan 50\% dari penduduk berusia diatas 50 tahun sehingga istilah Babby Boom pada masa lalu berganti menjadi "ledakan penduduk lanjut usia" (lansia). ${ }^{1}$

Inggris juga memiliki populasi lansia (> 65 tahun) telah mengalami peningkatan 1,5 juta orang selama 25 tahun terakhir yang mencerminkan 16\% dari populasi. Angka harapan hidup saat kelahiran meningkatkan secara bertahap di inggris : bayi baru lahir berjenis kelamin laki-laki memiliki harapan hidup hingga usia 76,6 tahun dan bayi baru lahir berjenis kelamin perempuan mencapai usia 81,0 tahun jika angka mortalitas tidak berubah. ${ }^{2}$

Di seluruh dunia penduduk lansia (usia > 60 tahun) tumbuh dengan sangat cepat bahkan tercepat dibanding kelompok usia lainnya. Diperkirakan mulai tahun 2010 akan terjadi ledakan jumlah penduduk lanjut usia. Hasil prediksi menunjukkan bahwa persentase penduduk lanjut usia akan mencapai 9,77\% dari total penduduk pada tahun 2010 dan menjadi $11,54 \%$ pada tahun 2020. Begitu juga di Indonesia mengalami peningkatan yang signifikan pada tahun 2007, jumlah penduduk lanjut usia sebesar 18,96 juta jiwa dan meningkat menjadi 20.547.54 pada tahun 2009. Jumlah ini termasuk terbesar keempat setelah Cina, India dan Jepang. Badan kesehatan dunia WHO menyatakan bahwa penduduk lansia di Indonesia pada tahun 2020 mendatang sudah mencapai angka 11,34\%/tercatat 28,8 juta jiwa dan tahun 2025 kenaikan jumlah lansia bisa mencapai sebesar $41,4 \%$. Hal ini menyebabkan jumlah penduduk lansia di Indonesia terbesar di dunia. ${ }^{3}$

Keberadaan lansia seringkali dipersepsikan secara negatif dan keliru, dimana lansia itu sendiri dianggap sebagai beban keluarga ataupun masyarakat sekitarnya. Hal ini muncul dikarenakan melihat dari kasuistik (perekaman dan penelitian sebab-sebab (kasus-kasus) masalah) terhadap lansia (jompo) yang hidupnya sangat tergantung kepada orang. Persepsi negatif seperti ini sesungguhnya tidak sepenuhnya benar, karena masih banyak lansia yang masih dapat beraktifitas semampunya atau bisa disebut juga berperan aktif, baik dalam keluarga maupun dalam lingkungan masyarakat tempat dia tinggal. Lansia merupakan suatu proses yang alami yang tidak dapat dihindari. Orang menjadi tua ditandai dengan kemunduran-kemunduran biologis yang pada lahirnya terlihat gejala-gejala kemunduran fisik diantaranya kulit mengendor, wajah keriput, rambut mulai berubah putih, gigi mulai ompong, penglihatan dan pendengaran manjadi buruk, cepat dan mudah lelah dan kerampingan tubuh mulai menghilang.

Kebutuhan dasar manusia merupakan unsur-unsur yang dibutuhkan oleh manusia dalam menjaga keseimbangan baik secara fisiologis maupun psikologis yang bertujuan untuk mempertahankan kehidupan dan kesehatan.Teori Hierarki kebutuhan yang dikemukakan oleh Abraham Maslow menyatakan bahwa setiap manusia memiliki lima kebutuhan dasar, yaitu : Pertama kebutuhan fisiologis (Physiological needs), yang merupakan kebutuhan paling dasar pada manusia. Antara lain ; pemenuhan kebutuhan oksigen dan pertukaran gas, cairan (minuman), nutrisi (makanan), eliminasi, istirahat dan tidur, aktivitas, keseimbangan suhu tubuh, serta seksual. Kedua kebutuhan rasa aman dan perlindungan (need for security and protection), dibagi menjadi perlindungan fisik dan perlindungan psikologis. Perlindungan fisik, meliputi perlindungan dari ancaman terhadap tubuh dan kehidupan seperti kecelakaan, penyakit, bahaya lingkungan, dan lain lain. Perlindungan psikologis, perlindungan dari ancaman peristiwa atau pengalaman baru atau asing yang dapat mempengaruhi kondisi kejiwaan seseorang. Ketiga kebutuhan rasa cinta (needs love), yaitu kebutuhan untuk memiliki dan dimiliki, memberi dan menerima kasih sayang, kehangatan, persahabatan, dan kekeluargaan. Keempat kebutuhan akan harga diri (the need for self) dan perasaan dihargai 
oleh orang lain serta pengakuan dari orang lain. Kelima adalah kebutuhan aktualisasi diri (self actualization needs), ini merupakan kebutuhan tertinggi dalam hierarki Maslow, yang berupa kebutuhan untuk berkontribusi pada orang lain atau lingkungan serta mencapai potensi diri sepenuhnya. ${ }^{4}$

Salah satu bentuk pemenuhan kebutuhan fisiologis berdasarkan pendapat dari Abraham Maslow yaitu makan. Pola kebiasaan makan yang tidak baik juga merupakan salah satu penyebab timbulnya masalah kesehatan salah satunya adalah konstipasi. Masalah ini sering terjadi pada mereka yang mengkonsumi makanan rendah serat. Pada lansia pemenuhan makanan yang berserat kurang terpenuhi, ini dikarenakan lansia dari segi fisik kurang mendukung yaitu gigi lansia yang tidak utuh dan dari segi dukungan keluarga juga dapat dikarenakan keluarga yang kurang memenuhi asupan nutrisi tinggi serat pada lansia itu sendiri. Hal-hal tersebut juga menyebabkan kurangnya kemampuan membentuk masa feses yang baik, guna merangang peristaltik usus. Jika rangsangan peristaltik usus menurun maka akan terjadi konstipasi, kemudian feses akan mengeras dan dapat menyumbat lumen usus sehingga menyebabkan gejala konstipasi (sembelit). Konstipasi yang terjadi pada lansia berbeda dengan konstipasi pada usia muda, sebagian besar problem konstipasi pada lansia berhubungan dengan penurunan totalitas kolon terbatas ke anorekturo, yaitu berupa kegagalan relaksasi otot-otot di dasar pinggul selama proses defekasi. ${ }^{5}$

Adapun pengertian dari konstipasi itu sendiri adalah suatu keadaan dimana seseorang mengalami kesulitan buang air besar atau jarang buang air besar. Konstipasi dibagi menjadi dua yaitu akut dan kronik. Konstipasi akut biasanya dimulai secara tiba-tiba dan tampak dengan jelas, sedangkan konstipasi kronik mulainya tidak jelas dan menetap selama beberapa bulan atau bahkan tahun. Kondisi dimana feses memiliki konsistensi keras dan sulit dikeluarkan juga bisa disebut konstipasi. Adapun persepsi gangguan buang air besar berupa berkurangnya frekuensi buang air besar, sensasi tidak puasnya Buang Air Besar (BAB), terdapat rasa sakit saat mengeluarkan feses dan harus mengejan dengan keras itu juga bisa disebut dengan konstipasi. ${ }^{5}$

Lansia yang memakan makanan tinggi serat biasanya lebih jarang yang mengalami konstipasi. Diet rendah serat juga memegang peranan yang sangat penting untuk timbulnya konstipasi pada usia lanjut. Emosi yang kuat dapat menyebabkan konstipasi dengan menghambat gerak peristaltik usus melalui kerja dari epinefrin dan system syaraf simpatis. Stress juga dapat menyebabkan usus spastik (spastik/konstipasi hipertonik atau iritasi colon). ${ }^{6}$

Usia lanjut yang dapat mempengaruhi proses pengosongan lambung. Diantaranya adalah atony (berkurangnya tonus otot yang normal) dari otot-otot polos colon yang dapat berakibat pada melambatnya peristaltik dan mengerasnya feses sehingga memungkinkan terjadinya konstipasi. ${ }^{6}$

Konstipasi pada lanjut usia lebih sering terjadi pada lanjut usia umur 60 tahun, sebagian besar konstipasi pada lanjut usia berhubungan dengan penurunan motilitas kolon, berkurangnya mobilitas aktifitas fisik, rendahnya asupan serat dan asupan cairan pada lanjut usia. $^{7}$

Menurut informasi mengenai jumlah serat yang dikonsumsi sehari oleh lansia menunjukkan bahwa rata-rata asupan serat makanan yaitu $16 \mathrm{gr} / \mathrm{hr}$ atau $11 \mathrm{gr} / \mathrm{hr}$ untuk lansia. Status hidrasi yang rendah dapat memperburuk konstipasi pada lanjut usia, karena pada umumnya lanjut usia membatasi asupan cairan yang dapat menyebabkan seringnya buang air kecil. Perubahan rasa haus dimana rasa dahaga menurun (hipodipsia) berkurang kemampuan untuk mensekresi urin dan mempertahankan body water terjadi pada lansia menyebabkan risiko tinggi terjadi dehidrasi. Untuk itu dianjurkan untuk mengkonsumsi air sebanyak 1500 $2000 \mathrm{cc}$ perhari atau $30 \mathrm{cc} / \mathrm{kg} \mathrm{BB} /$ hari. $^{7}$

Konstipasi biasa terjadi pada wanita dibandingkan pria bila diukur dalam perbandingan yaitu 3:1 higga 2:1. Kejadian konstipasi meningkat seiring bertambahnya usia, 
teruatama pada usia 65 tahun keatas. Pengobatan konstipasi pada lansia harus sedini mungkin, bila tidak konstipasi akan menjadi kronik, dan makin sulit mengobatinya apalagi bila telah terjadi pengaruh kejiwaan. ${ }^{7}$

Wilayah Kota dan Kabupaten Cirebon memiliki beberapa panti sosial yang menampung beberapa lansia dengan berbagai masalah kesehatan terutama masalah kesehatan konstipasi. Dari hasil studi pendahuluan yang dilakukan oleh peneliti pada tanggal 7 November 2016 yang dilakukan di 3 panti di wilayah Cirebon berdasarkan data kesehatan dari 28 lansia yang tinggal di panti tersebut semua lansia pernah mengalami konstipasi karena pola makan lansia yang tidak tinggi serat dan cukup cairan. Adapun faktor lain terjadinya konstipasi pada lansia yaitu tingkat kecemasan, istirahat yang kurang dan dukungan dari keluarga. ${ }^{8}$

Dalam penelitian tentang konstipasi pada lansia di panti wreda yang ada di wilayah Cirebon peneliti memilih panti Siti Khodijah, panti Kasih, dan panti Kasih Ibu karena lansia bersedia dijadikan sebagai responden dan pihak panti mengijinkan peneliti untuk melakukan penelitian di panti tersebut.

Tujuan penelitian ini untuk mengetahui pengaruh asupan tinggi serat dan cairan terhadap terjadinya konstipasi pada lansia di panti Wredha Wilayah Cirebon Tahun 2017.

\section{METODE PENELITIAN}

Penelitian ini menggunakan jenis penelitian pra eksperimen dengan bentuk rancangan penelitian one group-pretest-posttest. ${ }^{9}$

Populasi dalam penelitian ini adalah lansia yang berada di Panti Wredha Wilayah Cirebon dengan jumlah 28 orang. ${ }^{10}$ Sedangkan teknik sampel yang digunakan adalah total sampling, yaitu seluruh lansia di 3 panti wredha wilayah Cirebon yang berjumlah 28 orang dengan rincian lansia yaitu panti Siti Khodijah berjumlah 14 orang, panti wredha Kasih berjumlah 7 orang, dan panti wredha Kasih Ibu berjumlah 7 orang. Instrumen atau alat-alat dalam penelitian ini adalah kuesioner (daftar pertanyaan dengan wawancara langsung terhadap objek penelitian dan menggunakan FFQ (Food Frequency Questionnaire) untuk mengetahui frekuensi asupan tinggi serat dan cairan yang cukup pada lansia. Sedangkan analisa yang digunakan adalah analisa univariat dan bivariat.

\section{HASIL PENELITIAN DAN PEMBAHASAN}

\section{Karakteristik Responden}

Tabel 1. Distribusi Frekuensi Berdasarkan Karakteristik Respoden Menurut Usia.

\begin{tabular}{ccc}
\hline \multicolumn{1}{c}{ Usia } & Frekuensi & Persentase (\%) \\
\hline$<60$ tahun & 9 & 32,1 \\
$61-70$ tahun & 12 & 42,9 \\
$>71$ tahun & 7 & 25,0 \\
\hline Jumlah & 28 & 100,0 \\
\hline
\end{tabular}

Berdasarkan usia didapatkan hasil penelitian bahwa sebagian besar responden berusia 61-70 tahun yaitu sebanyak 12 orang $(42,9 \%)$. 
Tabel 2. Distribusi Frekuensi Berdasarkan Karakteristik Respoden Menurut Jenis Kelamin.

\begin{tabular}{ccc}
\hline Jenis Kelamin & Frekuensi & Persentase $(\%)$ \\
\hline Laki- Laki & 2 & 7,1 \\
Perempuan & 26 & 92,9 \\
\hline Total & 28 & 100,0 \\
\hline
\end{tabular}

Berdasarkan jenis kelamin didapatkan hasil penelitian bahwa sebagian besar responden berjenis kelamin perempuan sebanyak 26 orang $(92,9)$.

\section{Sebelum Dilakukan Terapi Asupan Tinggi Serat Dan Cairan}

Tabel 3. Distribusi frekuensi sebelum diberikan asupan tinggi serat dan cairan terhadap terjadinya konstipasi pada lansia di panti wredha wilayah Cirebon tahun 2017.

\begin{tabular}{ccc}
\hline $\begin{array}{c}\text { Sebelum asupan tinggi serat } \\
\text { dan cairan }\end{array}$ & Frekuensi & Persentase (\%) \\
\hline$>15$ & & 85,7 \\
$<15$ & 24 & 14,3 \\
\hline Total & 4 & 100,0 \\
\hline
\end{tabular}

Berdasarkan distribusi frekuensi sebelum diberikan asupan tinggi serat dan cairan sebagian besar mengalami konstipasi sebanyak 24 orang $(85,7 \%)$ dan tidak konstipasi sebanyak 4 orang $(14,3 \%)$.

\section{Sesudah Dilakukan Terapi Asupan Tinggi Serat Dan Cairan}

Tabel 4. Distribusi frekuensi sesudah diberikan asupan tinggi serat dan cairan terhadap terjadinya konstipasi pada lansia di panti wredha wilayah Cirebon tahun 2017.

\begin{tabular}{ccc}
\hline $\begin{array}{c}\text { Sesudah asupan tinggi serat } \\
\text { dan cairan }\end{array}$ & Frekuensi & Persentase $(\%)$ \\
\hline$>1700$ kalori & 28 & 100,0 \\
$<1700$ kalori & 0 & 0 \\
\hline Total & 28 & 100,0 \\
\hline
\end{tabular}

Berdasarkan distribusi frekuensi sesudah diberikan asupan tinggi serat dan cairan semua responden mengalami asupan tinggi serat dan cairan cukup sebanyak 28 orang (100\%).

\section{Pengaruh Asupan Tinggi Serat dan Cairan Terhadap Terjadinya Konstipasi Pada Lansia}

Tabel 5. Hasil pengukuran konstipasi sebelum dan sesudah dilakukan terapi asupan tinggi serat dan cairan.

\begin{tabular}{lccc}
\hline Variabel & Mean & Standar Deviasi & $P$ Value \\
\hline Sebelum terapi & 1,14 & 0,356 & 0,046 \\
Sesudah terapi & 1 & 0,000 & \\
\hline
\end{tabular}

Dari hasil penelitian yang telah dilakukan diperoleh bahwa konstipasi pada lansia mengalami penurunan sesudah dilakukan terapi asupan tinggi serat dan cairan. Penurunan konstipasi pada lansia ini diperoleh dari pengukuran konstipasi pada lansia sebelum dan 
sesudah dilakukan terapi asupan tinggi serat dan cairan dengan menggunakan uji wilcoxon. Hasil rata-rata uji wilcoxon ini sebelum dilakukan terapi asupan tinggi serat dan cairan adalah 1,14 dan standar deviasinya 0,356 dan hasil rata-rata sesudah dilakukan terapi asupan tinggi serat dan cairan adalah 1,00 dan standar deviasinya adalah 0,000. Hasil ini menunjukan bahwa nilai $\mathrm{p}<0,05(0,046)$ yang berarti terdapat pengaruh yang signifikan. Maka dari hasil dari uji wilcoxon tersebut diketahui bahwa asupan tinggi serat dan cairan sangat efektif terhadap terjadinya konstipasi pada lansia.

\section{PEMBAHASAN}

\section{Pengaruh Terapi Asupan Tinggi Serat Dan Cairan Terhadap Terjadinya Konstipasi Pada Lansia}

Hasil rata-rata uji wilcoxon ini sebelum dilakukan terapi asupan tinggi serat dan cairan adalah 1,14 dan standar deviasinya 0,356 dan hasil rata-rata sesudah dilakukan terapi asupan tinggi serat dan cairan adalah 1,00 dan standar deviasinya adalah 0,000. Hasil ini menunjukan bahwa nilai $\mathrm{p}<0,05(0,046)$ yang berarti terdapat pengaruh yang signifikan. Maka dari hasil dari uji wilcoxon tersebut diketahui bahwa asupan tinggi serat dan cairan sangat efektif terhadap terjadinya konstipasi pada lansia.

Dari hasil penelitian para responden yang diberi asupan tinggi serat, sebagian besar tidak mengalami konstipasi, karena telah kita ketahui konsumsi serat yang teratur dapat memperlancar sistem pencernaan. Serat yang mampu berikatan dengan air menyebabkan volume feses menjadi lunak dan besar. Akibat membesarnya volume feses maka saraf rectum akan semakin cepat ke saluran pencernaan paling bawah, dan feses mudah untuk dikeluarkan, tetapi masih ada responden yang mengalami konstipasi hal ini dibuktikan dengan masih adanya keluhan yang terlihat yaitu keluhan mengejan keras saat BAB, keluhan massa feses yang keras dan sulit keluar serta keluhan rasa sakit pada perut saat BAB. Keluhan-keluhan tersebut masih timbul karena responden dalam pelaksanaan diet tinggi serat masih kurang baik, disebabkan oleh faktor kebiasaan makan makanan lain dan juga karena kebiasaan BAB yang kurang baik seperti sering menahan untuk segera BAB. Selain itu masih terjadinya konstipasi dimungkinkan karena dipengaruhi oleh faktor kurang olahraga/aktifitas juga dapat mempengaruhi terjadinya konstipasi pada lansia dan juga asupan air putih yang kurang. ${ }^{11}$

Hasil penelitian ini sama dengan hasil penelitian yang dilakukan oleh Sari (2011) dan Oktaviana (2013) dimana konsumsi makanan dengan serat rendah berpengaruh terhadap pola defekasi yaitu terjadinya konstipasi. ${ }^{12,13}$

Namun hasil penelitian ini berbeda dengan yang dilakukan oleh Ambarita et al (2014) dan Fitriani (2011) dimana mengkonsumsi makanan yang mengandung serat tidak memiliki hubungan yang bermakna dengan pola defekasi. ${ }^{14,15}$

Hal ini dapat terjadi karena perbedaan cara pengolahan makanan yang menjadi sumber serat. Pemanasan yang berlebihan pada makanan yang menjadi sumber serat dapat merusak struktur serat sehingga fungsi serat menjadi tidak optimal. ${ }^{10}$ Serat dalam bentuk mentah atau dimasak cukup sampai lunak dan tidak sampai lembek dapat mengurangi kerusakan struktur dan mengoptimalkan fungsi. ${ }^{10}$ Sesuai dengan penelitian yang dilakukan oleh Kusumawati danWidyaastuti bahwa pola defekasi tidak hanya dipengaruhi oleh konsumsi serat tetapi juga dari cara pengolahannya. ${ }^{16}$

\section{SIMPULAN} berikut:

Berdasarkan hasil penelitian dan pembahasan, makan dapat ditarik kesimpulan sebagai

1. Berdasarkan hasil penelitian didapatkan hasil bahwa sebelum diberikan asupan tinggi serat dan cairan sebagian besar mengalami konstipasi sebanyak 24 orang $(85,7 \%)$. 
2. Berdasarkan hasil penelitian didapatkan hasil bahwa sesudah diberikan asupan tinggi serat dan cairan semua responden mengalami asupan tinggi serat dan cairan cukup sebanyak 28 orang $(100 \%)$.

3. Berdasarkan hasil penelitian didapatkan hasil bahwa setelah dilakukan pengujian dengan uji wilcoxon adalah $\mathrm{p}<0,05$ yaitu 0,046, maka Ho ditolak dan Ha diterima berarti asupan tingi serat dan cairan berpengaruh terjadinya konstipasi pada lansia.

\section{SARAN}

1. Bagi Pendidikan Keperawatan STIKes Cirebon

Penelitian ini dapat dijadikan sumber informasi ilmiah dan dapat juga dijadikan bahan buku ajar mata kuliah kesehatan lansia.

2. Bagi Peneliti Selanjutnya

Sebaiknya menggunakan sampel dengan jumlah yang lebih besar. Pemberian terapi asupan tinggi serat dan cairan hendaknya dilakukan dengan cara yang lebih mudah dan dapat menghasilkan hasil yang lebih akurat.

3. Bagi Tenaga Kesehatan

Dapat menyebarluaskan metode pemberian terapi asupan tinggi serat dan cairan, terutama pada lansia yang tinggal di luar panti asuhan.

4. Bagi panti Wredha Wilayah Cirebon

Hasil penelitian ini dapat menjadi bahan masukan dan pertimbangan dalam upaya memberikan pelayanan dan intervensi keperawatan pada lansia yang sedang mengalami masalah konstipasi karena asupan serat yang rendah dan cairran yang kurang.

5. Bagi Responden

Dapat tetap menerapkan intervensi terapi asupan tinggi serat dan cairan yang cukup.

\section{DAFTAR PUSTAKA}

1. Nugroho, Wahjudi. Keperawatan Gerontik Edisi 2. Jakarta: EGC;2000.

2. Webster-Gandy. Gizi \& Dietetika Edisi 2. Jakarta: EGC; 2016.

3. Sholikhah, Siti. Pengaruh Diet Tinggi Serat Terhadap Konstipasi Pada Lansia Di Dukuh Patihan Desa Trucuk Kecamatan Trucuk Kabupaten Bojonegoro Tahun 2013. [Diakses tanggal 7 November 2016]. Diunduh dari http://stikesmuhla.ac.id/

4. Paula, dkk. Proses Keperawatan. Jakarta: Edisi 4 EGC;2009.

5. Ahriku. Konstipasi. [Diakses tanggal 7 November 2016]. Diunduh dari http://ahriku.wordpress.com/2010/02/08/konstipasi/

6. Burrner \& Suddarth. Keperawatan Medical Bedah. Jakarta : EGC; 2002.

7. Arif, Irfan. 2002. Konstipasi Pada Lansia. (Diakses tanggal 8 November 2016). Diunduh dari : www.susukolostrum.com.

8. Fajar, dkk. 2011. Principles of Nutritional Assessment. New York: Oxford University Press,inc. (Diakses tanggal 9 November 2016). Diunduh dari : http://repository.ipb.ac.id

9. Notoatmodjo, Soekidjo. Metodologi penelitian kesehatan. Jakarta : Rineka Cipta; 2010

10. Sugiyono. Metode Penelitian Kuantitatif Kualitatif Dan R\&D. Bandung : Alfabet; 2015.

11. Sholikhah, Siti. Pengaruh Diet Tinggi Serat Terhadap Konstipasi Pada Lansia Di Dukuh Patihan Desa Trucuk Kecamatan Trucuk Kabupaten Bojonegoro Tahun 2013. (Diakses tanggal 18 Desember 2016). Diunduh dari : http://stikesmuhla.ac.id

12. Sari AK. Hubungan Pola Makan Berserat Dengan Kejadian Konstipasi Dirumah Sakit Haji Adam Malik Tahun 2011 (Skripsi). Medan: Universitas Sumatera Utara;2011

13. Oktaviana ES. Hubungan asupan serat dan faktor-faktor lain Dengan Konstipasi Fungsional Pada Mahasiswi Reguler Gizi Fakultas Kesehatan Masyarakat Universitas Indonesia Tahun 2013 (skripsi). Depok: Universitas Indonesia; 2013.

14. Fitriani, Imel. Hubungan Asupan Serat Dan Cairan Dengan Kejadian 
Konstipasi Pada Lanjut Usia Di Panti Sosial Sabai Nan Aluih Sicincin Tahun 2010. Penelitian, Fakultas Keperawatan. (Diakses tanggal 18 Desember 2016). Diunduh dari : http://repo.unand.ac.id/id

15. Ambarita EM, dkk. Hubungan Asupan Serat Makanan Dan Air Dengan Pola Defekasi Anak Sekolah Dasar Di Kota Bogor. Jurnal Gizi dan Pangan; 2014

16. Kusumawati FD, Widyaastuti EE. Hubungan Antara Kecukupan Konsumsi Serat Terhadap Pola Defekasi Dan Ukuran Lingkar Perut Di Kelurahan Mekar Jaya Kecamatan Sukma Jaya Kota Depok (Skripsi). Jakarta: Universitas Indonesia;2009. 